\title{
The analysis of Pedroni Co-integration and VECM on export performance and exchange rate fluctuation
}

\author{
Suraya Mahmood ${ }^{1}$, Hammed Oluwaseyi Musibau ${ }^{1, *}$, Abdullahi Masud $^{2}$ \\ 1 Faculty of Economy and Management sciences, Universiti Sultan Zainal Abidin (UniSZa), Kuala Terengganu, Malaysia \\ ${ }^{2}$ Department of Business Administration, Ibrahim Badamasi Babangida University lapai, Niger State, Nigeria
}

\section{A R T I C L E IN F O}

\section{Article history:}

Received 8 July 2017

Received in revised form

13 September 2017

Accepted 20 September 2017

\section{Keywords:}

Real exchange rates

Export

Interest rate

Money demand

Economic growth

Inflation

\section{Introduction}

Before the introduction of a deregulated economy in Nigeria in the year 1986, the direction and growth of external trade in Nigerian economy were on a favorable path as the exports were improving. But, there is a substantial dependent on foreign exchange allocation and managed exchange rate contributed in complicating issues thereby helping the external sector reel in continued deficit. This exerted pressure on the official foreign exchange market and made the international trade targets of the period to continually unrealized due to the deficit. With the deregulation of the economy in 1986, a market based framework for the determination of exchange rate was introduced. It was predicted that the realization of favorable balance of trade will result to eradication of falsifications in the sector and improve growth in the balance of payments accounts, encourage non-oil exports, increase foreign exchange inflows, moderate demand pressure in the foreign exchange utilizations. The achievement of a realistic exchange rate was also expected to make the parallel market premium ineffective, decrease capital flight and improve the inflow of foreign investment (Aliyu, 2010).

\footnotetext{
* Corresponding Author.

Email Address: mizbauhameed2010@gmail.com (H. O. Musibau) https://doi.org/10.21833/ijaas.2017.011.007

2313-626X/C) 2017 The Authors. Published by IASE.

This is an open access article under the CC BY-NC-ND license

(http://creativecommons.org/licenses/by-nc-nd/4.0/)
}

\begin{abstract}
A B S T R A C T
The study investigates the relationship between exchange rate fluctuation export in Nigeria. Based on the findings, the study suggests that Nigeria
\end{abstract} 2017 The Authors. Published by IASE. This is an open access article under the CC BY-NC-ND license (http://creativecommons.org/licenses/by-nc-nd/4.0/)

Evidence of exchange rate depreciation has underspin the Nigeria's exchange rate activities. Exchange rate depreciation had on several times been adopted in Nigeria to address the balance of trade deficit in the economy. The depreciation will be usually being expected to bring about a significant development in Nigeria's balance of trade. But then again the depreciation has end up in the reduction of value of the Country's exports, thus causing decline in balance of trade. It is based on this statement that the study aims at influencing the effect of exchange rate discrepancy on Nigeria's balance of trade. The main reason of this study is to correct these sensitive issues. This research study anticipates providing an empirical basis for the analysis of the impact of price and exchange rate changes on the balance of trade. If devaluation is expected to strongly affect the balance of trade, then a most important impact must come through an adjustment of export trade balance rather than through adjustment of a portfolio (Blanchard et al., 2010).

Therefore, the purpose of this paper is to close this gap of very limited studies on the matter on these countries and provide estimates of the shortand long-run impact of exchange rate variability on export performance in Nigeria.

\subsection{Problem statement}

The influence of rise in exchange rate variability on Export trade has been examined in a huge number of empirical and theoretical studies for emerging nations and world generally. The issue is particularly important for countries like Nigeria that 
switched from a fixed to a flexible exchange rate regime due to the higher degree of variability connected with flexible exchange rates. The collapse of the Bretton woods system in the 1970s led to the adoption of the floating exchange rate regime. The issue on fluctuations in exchange rate in Nigeria has created a lot of cancer in Nigerian economy with high rate of inflation, interest rate and unfavorable balance of payments. It has also tended to undermine the international competitiveness of nonoil exports and make planning and projections difficult at both micro and macro levels of the economy. A good number of small and medium scale enterprises have been strangled out as a result of low dollar/ naira exchange rate and so many other problems resulting from fluctuations in exchange rates can also be identified. More so, the issue of fluctuation in Naira has reduced the activities of potential investors in Nigeria because it increases uncertainty over the returns of a given investment. Potential investors will invest in a foreign location only if the expected returns are high enough to cover for the currency risk. However, Nigerian exchange rate was relatively stable in 2003 and between 2005 and 2008 Naira appreciated. The Naira -dollar exchange rate as at 2011 was $\$ 162.30$ but fell to $\$ 156.15$ in 2012 and a further decline to $\$ 155.73$ in 2013. The Naira-Dollar exchange value was highly volatile towards the end of 2014 and in 2015 with \#168 for 1 USD, 204 for 1 USD in February 2015, \#305.6 to 1USD in 2016 and 2017 is $\$ 365$ to 1USD. In addition, the various exchange rate systems in used in Nigeria had also failed to eliminate or reduce the incidence of capital flight and the power to correct the sky rocketing Naira exchange rate has been missing.

\section{Literature review}

Exchange rate is referred to as the way in which one foreign currency is exchanged from person to another according to Digrigoli and Lee (2010) that is, the price of one Currency in terms of another Currency. Therefore, the exchange rate between the dollar and the naira refers to the number of naira required to purchase a dollar. According to Lane and Shambaugh (2010) the exchange rate of a particular Currency measured the worth of a domestic economy in terms of another. The exchange rate measures the external value of a Currency provides a direct association between foreign and domestics prices of goods and services (Abbott and De Battisti, 2011). Variation is a change to a price or interests. Prices may vary according to supply and demand. Interest rates may remain the same, but their changes are generally more controllable to some extent.

Prior studies have used time series analysis and found to be insignificant association between trade and volatility. Only few research studies that found a relationship which suggested that the impact was very insignificant (Aliyu, 2010). However, Faust et al. (2003) in his studies which preluded that the co- integration literature, prediction exchange rates by simply regressing the exchange rate on the macroeconomic fundamentals and then using these indices to estimates and the ex post appreciate and reviewed the values of the impending economic fundamentals to predict the imminent exchange rate. A cross-sectional research studies also conducted by Rose and Spiegel (2010) and Chit et al. (2010) found a negative impact of exchange rate changes on export. Once more, this impact, in most cases, was relatively small. Baum and Caglayan (2010) disclosed evidence of a positive association between exchange rate changes and trade using flexible lag Poisson structure, while Klaassen (2004) didn't find evidence of any significant impact of exchange rate fluctuation on G7 trades economies. Similarly, Huchet-Bourdon and Bahmani-Oskooee (2013) examined the effect of RMB- dollar fluctuation on exchange rate in United States. Agricultural imports and exports from China using GARCH-based and moving standard deviation of the real RMB-dollar rate, which brings more important results. They concluded that fluctuation in exchange rate is significant and has long run association on the import price of both non-agricultural sector and on export earnings of the agricultural sector. This supports the finds of Erdal et al. (2012). Also, Zmami and Ben-Salha (2015) investigated the effect of exchange volatility was examined on micro dataset of 548 Manufacturing companies in Tunisia for period of 1997-2002 using GMM techniques. They found a positive association between employment and changes in exchange rate. In addition, the degree of responsive of exchange rate to employment varies from firm to firm. Finally, employing different methods of volatility, it was established that the exchange rate volatility significantly lowers the employment level in all types of firms.

Aliyu (2010) applied a model of gravitational for Nigeria-India mutual trade and revealed that the exchange rate coefficient is academically consistent and statistically significant in the import model for the Indian economy but not for the Nigerian economy. Contrary to the outcome of Nigeria policy that is unfavorable monetary policy, growth in money supply, interest rate, and inflation and the $f$ monetary policy failure was associated with fiscal dominance in the economy.

Chit et al. (2010) also established a negative relationship between non-oil export and exchange rate volatility in Nigeria between 1986 and 2006 employed standard deviation measure with quarterly observation. However, Adeoye and Atanda (2011) studied the influence of oil price shock and exchange rate volatility on economic growth in Nigeria. They examined the volatility in term of consumer price index based on approach of real exchange But unable to examine the persistency of exchange rate volatility appropriate econometric approach. Also, Greenaway et al. (2010) examined the impact of exchange rates volatility on company's Exports through two stage selection model. The outcome discloses that companies that export have 
the advantage to be greater, or even more creative than external owned. Chit et al. (2010) investigated the activities of financial development sector in influencing the effect of exchange rate instability on the exports of five developing countries Asia east such as Malaysia, Thailand, Indonesia, and China. The outcome shown that the impact of exchange rate changes on exports is temporary on the financial development sector. The weaker an economy financially developed, the more its exports are affected badly by exchange rate instability. More so, the exchange rate that is stable the better it seems to be achievable in export promotion through currency devaluation in these economies. The econometric approach used is found not appropriate for only 4 countries. GMM is used when $\mathrm{N}$ is greater than $\mathrm{T}$. Dincer and Kandil (2011) examined effect of exchange rate volatility on export in Turkey over period of 1996 to 2003 and also 2003 to 2008 with 21 exporting companies. They found asymmetric effects between endogenous and exogenous. However, Aliyu (2010) summited that the exchange rate appreciation may bring an improvement in imports and decreases export whereas devaluation will increase export and decreases import. Similarly, exchange rate depreciation tends to cause a shift from foreign products to domestic products or services. Therefore, it may bring a diversion of proceeds from importing countries to countries exporting via a shift in terms of trade, and this may have a tendency to to have an effect on the exporting and importing countries'. Erdal et al. (2012) also examined the impact of exchange volatilities on agriculture export and import for period of 1995 to 2007. The long run association was established via Johansen co-integration test and Granger causality. The result supported by Dhasmana (2012). Also, Caglayan and Demir (2014) investigated the impact of real exchange rate instability on companies' exporting from 28 emerging economies. They used GMM dynamic panel data estimator for the research study. The study positive relationship exchange rate flexibility and trade flows in developing economies.

In aggregate, numerous researches have conflicting result with regards to the effect of real exchange rate fluctuation on the export in Nigeria, some found positive relationship while others established a negative relationship. Methodologically, Ordinary Least Square, cointegration and other statistical approaches had been employed, little or none is ascribed to combine both co-integration and granger causality. Therefore, the purpose of this paper is to close this gap of very limited studies on the matter on these countries and provide estimates of the short- and long-run impact of exchange rate variability on export performance in Nigeria.

\subsection{Theoretical framework}

Theoretically, it is expected that growth in real GDP of trading partners will lead to a greater volume of exports of the trading partners. While, real exchange rate depreciation may lead to a rise in exports due to the price effect. Traditional comparative advantage models argue that variances in resource bequest and technology are major factor in determining comparative advantage and the trade pattern of a country. The paper adopted traditional comparative advantage the theory predicts that any policy encouraged trade pattern is sub-optimal. A proactive real exchange rate policy is an essential macroeconomic policy instrument that policy makers can use to impel the specialization pattern of a country.

\section{Methodology}

\subsection{Data and estimation method}

The study utilized data from Nigeria using cointegration and granger causality to examine the long run relationship between inflation, export, exchange rate, Gross domestic product money demand and interest rate.

\subsection{Model specification}

In an attempt to estimate effect of exchange rate on export in this research study we employed exchange rate, export, inflation, interest rate Money demand, and real gross domestic product. This study is specified as thus;

$\operatorname{InEXPT}_{t}=\beta_{0}+\beta_{1} \operatorname{InREER}_{t-1}+\beta_{2} \operatorname{InREXX} X_{t-1}+\beta_{3} \operatorname{InINFL} L_{t-1}$
$+\beta_{4} \operatorname{InRINT} T_{t}+\beta_{5} \operatorname{InM} 22_{t-1}+\beta_{6} \operatorname{InGDP} \operatorname{PI}_{t-1}+\mu_{t}$

EXPT $_{t}=$ EXPTt is Export of Nigeria at period $t$. REER $_{\mathrm{t}-1}=$

The Real Exchange Rate of country $i$ at period $t$.

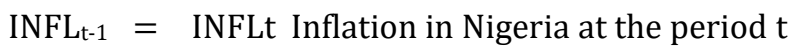
RINT $_{\mathrm{t}}=$ Real Interest Rate in Nigeria at period $\mathrm{t}$.

$\mathrm{M} 2 \mathrm{t}-1=$ Demand for Money in Nigeria at period $\mathrm{t}$

$\mathrm{GDP}_{\mathrm{t}-1}=$

Gross Domestic Product in Nigeria at period $t$

$\mu \mathrm{t}=$ Error Term at period $\mathrm{t}$

$\beta$ is a vector of coefficients, and , t denotes time

Brief explanation on Vector $\mathrm{X}$ as Independent Variables in Nigeria: The empirical studies conducted by different researchers that describes the total relationship between international trade and exchange rate at the country level but very limited research studies were investigated at the short and long relationship on exchange rate instability on total exports. Therefore, studies using aggregate data are subjected to expose with difficulties. These includes the bias aggregate (Dekle and Ryoo, 2007), simultaneity (Adolfson, 2001), and error measurement in constructing aggregate parameters. There is empirical effort on the responses of exports at the level of company otherwise a manufacturer. Concessions include (Berman et al., 2012; Chatterjee et al., 2013). Essentially, the current literature have stresses that 
company heterogeneity, such as productivity and the strength of imported inputs, may create exporters' response to exchange rate movements. Li et al. (2015) hinted that imported input intensity, a large distribution costs, and high income level of destination markets increase (decrease) the price (volume) responsiveness to exchange rate changes. However, ERPT is still high even after we have accounted for these factors work with a selected sample of products at HS-4 level during 1997- 2005. Together of their quantity and value regressions give coefficients about 0.9 , representing a very little RMB price response to exchange rate. In their study of French company, BMW disclosed that in reaction to a $10 \%$ appreciation, an average exporter cuts their export price in euro by between $0.5 \%$ and $1.4 \%$. In addition, among the studies on significant impact of monetary policy and interest rate on economic growth (Checherita-Westphal and Rother, 2012; Olawale and Garwe, 2010), It was proposed that developing markets economy that allowed the largest appreciation to increase in current account deficits and real exchange rate in the previous time of quantitative easing experienced reserve losses, stock market declines, and sharpest currency depreciation when tapering talk started. Second, fundamentals measures of policy and economic performance (the GDP rate of growth, the public debt, the level of reserves and the budget deficit) does not discuss that fundamentals better provided insulation better. Finally, Most of the research studies used Inflation as an parameter of macroeconomic instability in investigating exchange rate fluctuation and export performance maintained by Busse et al. (2016) which explained that, steady macroeconomic environment encourages both investments in an economy hence economic growth. High exchange rate value relative to the US dollar, which indicates that the depreciated currency, will, at equilibrium, attract higher foreign investments, therefore would improve the gross domestic product in the country. This is because exchange rate permits us to determine the effect of relative wealth and relative labor costs on investment inflows (Busse et al 2016). Thus, a depreciation of a country's exchange rate would increase the relative wealth of foreign company and this result to an increase in foreign purchases of domestic assets. Furthermore, a depreciation of a country's foreign exchange will lead to economic growth and capital inflow. In line with above literatures we used annual inflation rate as a measure for inflation (Busse et al., 2016).

In conclusion, secondary data were used in the study. We employed time series data of 35 years (1980-2015). The series consists of annual data for exchange rate, export, inflation, interest rate Money demand, and real gross domestic product of Nigeria. The data were collected and securitize from several sources i.e., Direction of Trade Statistics, political rating group (PRSG) and World Development Indicators.

\subsection{Pedroni Co-integration and VECM}

We have employed panel co-integration approach to perform co-integration analysis. This method is used to investigate the existence of the long run cointegration among the variables. If all series are stationary at first difference I (1). Another step is to test for the existence of a long-run co-integration and if Co-integrated then we proceed to Vector Error correction Model for long causality.

\section{Results and discussions}

To avoid producing spurious regression results, the study first carries out unit root test using the Augmented Dickey-Fuller (ADF) test. Unit root results are presented in Table 1.

Table1: Summary of ADF Unit root test result

\begin{tabular}{|c|c|c|c|c|c|c|}
\hline \\
\hline Variables & Level Data & First Difference & $1 \% \mathrm{CV}$ & $5 \% \mathrm{CV}$ & $10 \% \mathrm{CV}$ & Order of Integration \\
\hline EXPT & 2.05 & -7.51 & -4.28 & -3.56 & -3.22 & $\mathrm{I}(1)$ \\
\hline REER & -6.30 & -7.19 & -4.62 & -3.55 & -3.20 & I(1) \\
\hline INFL & -1.82 & -5.60 & -2.63 & -1.95 & -1.66 & $\mathrm{I}(1)$ \\
\hline M2 & -0.40 & -4.84 & -4.39 & -3.61 & -3.24 & I(1) \\
\hline GDP & -1.35 & -6.23 & -4.25 & -3.54 & -3.20 & $\mathrm{I}(1)$ \\
\hline INTR & -5.73 & -7.08 & -4.26 & -3.55 & -3.21 & $\mathrm{I}(1)$ \\
\hline
\end{tabular}

The outcome of the result suggests that the variables are integrated of order one, I (1) at 5 percent level of significance. Thus, the economic growth indicator GDP, follows an integrating I (1) process so that the stock market variables are a stationary process. So, all the variables can be carried forward for co-integration test. The result of the Johansen co-integration test which is used to assess the presence or otherwise of a long run relationship among the variables discloses the results. The outcome of the Johansen co-integration test is shown in Table 2 which uses Eq. 2.
EXPTt $=2013.623+6.33 E+08 R E E R t-1+1.59 E+$
$09(I N F L) t-1+1.78 E+09(R I N T) t-1+2.42 E+$
$09(M 2) t-1+0.322869($ InGDP $) t-1+\mu t$

The result of the Johansen Co-integration test indicates that a long run relationship exists among the variables. This is because both the max-eigen test and the trace statistic indicates two co-integrating equation in each case. There is long association between Exchange rate and Export in Nigeria. This is supported by Erdal et al. (2012). 
Table2: Johansen Co-integration test's result (Unrestricted Co-integration Rank Test (Trace))

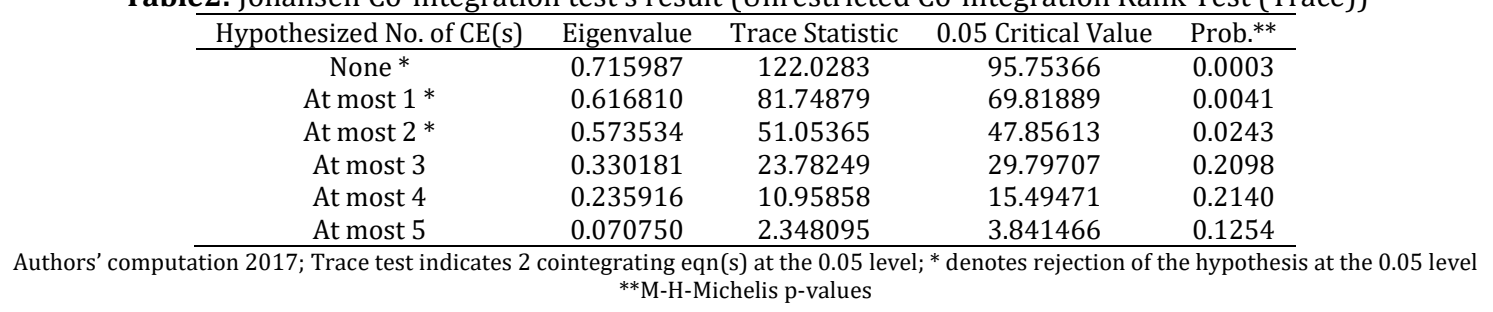

The exchange rate has an effect on the trade surplus (or deficit), which in turn affects the exchange rate, and so on. In general, however, a weaker domestic currency stimulates exports and makes imports more expensive. Conversely, a strong domestic currency hampers exports and makes imports cheaper. In the equation 3.04 above shows a negative relationship between exchange rate and export in Nigerian economy. This is in line with the study of Chit et al. (2010). The existence of at least one co-integrating equation per units is to estimate the over parameterize and the parsimonions ECM results. The summary of the over parameterize ECM result is shown in Table 3 which uses Eq. 3.

$D(E X P T) t=-3892 E+09-0.385 E C T t-1-0.076740 E X P T t-1-$ $1.15 E+08 I N F L t-1-1.57 E+09 R M 2 t-1+5.91 E+08 R E E R t-1$ 2.11E+08RINTt-1 +0.362670GDPt-1 + Et

Table 3: VECM results

\begin{tabular}{ccccc}
\hline Variable & Coefficients & Std Error & t-Statistic & Prob. \\
\hline Coint Eq1 & -0.384858 & 0.147357 & -2.611747 & 0.0177 \\
D(EXPT(-1)) & -0.076740 & 0.169351 & -0.453139 & 0.6559 \\
D(EXPT(-2)) & 0.393909 & 0.420269 & 0.937278 & 0.3610 \\
D(INFL(-1)) & $-1.15 E+08$ & $1.52 E+08$ & -0.752174 & 0.4617 \\
D(INFL(-2)) & $-1.87 E+08$ & $1.50 E+08$ & -1.246207 & 0.2287 \\
D(M2(-1)) & $-1.57 \mathrm{E}+09$ & $1.64 \mathrm{E}+09$ & -0.957458 & 0.3510 \\
D(M2 (-2)) & $-7.99 \mathrm{E}+08$ & $1.41 \mathrm{E}+09$ & -0.564831 & 0.5792 \\
D(REER(-1)) & $5.91 \mathrm{E}+08$ & $4.65 \mathrm{E}+08$ & 1.270453 & 0.2201 \\
D(REER(-2)) & $1.31 \mathrm{E}+08$ & $4.65 \mathrm{E}+08$ & 0.282763 & 0.7806 \\
D(RINT(-1)) & $-2.11 \mathrm{E}+08$ & $2.79 \mathrm{E}+08$ & -0.755758 & 0.4596 \\
D(RINT (-2)) & $261 \mathrm{E}+08$ & $2.87 \mathrm{E}+08$ & 0.911864 & 0.3739 \\
D(GDP(-1)) & 0.362670 & 0.071899 & 5.044177 & 0.0001 \\
D(GDP (-2)) & 0.388549 & 0.163227 & 2.380420 & 0.0286 \\
C & $-8.92 \mathrm{E}+09$ & $4.06 \mathrm{E}+09$ & -2.194203 & 0.0416 \\
\hline Authors' computation 2017; R- square: 0.74 F- Statistics 4.12 Durbin-
\end{tabular}

\section{Conclusion}

The research study investigates the exchange rate fluctuation on Nigerian export between the period 1980 to 2015. The study found that a long run association between exchange rate and export in Nigerian economy and significant. Nigerian exchange rate, inflation, interest rate, Money demand and Gross domestic product have significant impact on the Nigerian Export. Nigerian exchange rate has positive on the Export and all so, there is long run causality between Exchange rate and Export. The speed of adjustment toward long run equilibrium is 0.385 and found significant. The result showed 39 per cent speed towards equilibrium. The coefficient of determination is highly significant and the overall regression is also significant. The error correction coefficient is expectedly negative and highly significant at both $1 \%$ and $5 \%$ levels. This shows that there is long run equilibrium or association between Export and Real exchange rate and other variables i.e., at every 1 unit increase in Exchange Rate, Export will increase by 0.385 million since the speed of adjustment to equilibrium is 0.3857 . The Granger causality results at lag 2 show that there is no short causality with any reverse or feedback effect. The study recommends Nigeria to depreciate naira as a reduction in the exchange rate will reduce export prices, and, assuming demand is elastic, export revenue will increase.

\section{References}

Abbott P and De Battisti AB (2011). Recent global food price shocks: Causes, consequences and lessons for African governments and donors. Journal of African Economies, 20(1): $12-62$.

Adeoye BW and Atanda AA (2011). Exchange Rate Volatility in Nigeria: Consistency, Persistency \& Severity Analyses. CBN Journal of Applied Statistics, 2(2): 29-49.

Adolfson M (2001). Monetary policy with incomplete exchange rate pass-through. SSE/EFI Working Paper Series in Economics and Finance No. 476. Available online at: http://swopec.hhs.se/hastef/papers/hastef0476.pdf

Aliyu SUR (2010). Exchange rate volatility and export trade in Nigeria: An empirical investigation. Applied Financial Economics, 20(13): 1071-1084.

Baum CF and Caglayan M (2010). On the sensitivity of the volume and volatility of bilateral trade flows to exchange rate uncertainty. Journal of International Money and Finance, 29(1): 79-93.

Berman N, Martin P, and Mayer T (2012). How do different exporters react to exchange rate changes?. The Quarterly Journal of Economics, 127(1): 437-492.

Blanchard OJ, Das M, and Faruqee H (2010). The initial impact of the crisis on emerging market countries. Brookings Papers on Economic Activity, 2010(1): 263-307.

Busse M, Erdogan C, and Mühlen H (2016). China's impact on Africa-The role of trade, FDI and aid. Kyklos, 69(2): 228-262.

Caglayan M and Demir F (2014). Firm productivity, exchange rate movements, sources of finance, and export orientation. World Development, 54: 204-219.

Chatterjee A, Dix-Carneiro R, and Vichyanond J (2013). Multiproduct firms and exchange rate fluctuations. American Economic Journal: Economic Policy, 5(2): 77-110.

Checherita-Westphal C and Rother P (2012). The impact of high government debt on economic growth and its channels: An empirical investigation for the euro area. European Economic Review, 56(7): 1392-1405.

Chit MM, Rizov M, and Willenbockel D (2010). Exchange rate volatility and exports: New empirical evidence from the emerging East Asian Economies. The World Economy, 33(2): 239-263.

Dekle R, and Ryoo HH (2007). Exchange rate fluctuations, financing constraints, hedging, and exports: Evidence from 
firm level data. Journal of International Financial Markets, Institutions and Money, 17(5): 437-451.

Dhasmana A (2012). India's real exchange rate and trade balance: Fresh empirical evidence. Research Paper No. 373. Indian Institute of Management Bangalore. Available online at: https://papers.ssrn.com/sol3/papers.cfm?abstract_id=21534 01

Digrigoli G and Lee G (2010). Multicurrency exchanges between participants of a network-based transaction facility (U.S. Patent No. 7,742,985). Patent and Trademark Office, Washington, D.C., USA.

Dincer N and Kandil M (2011). The effects of exchange rate fluctuations on exports: A sectoral analysis for Turkey. The Journal of International Trade and Economic Development, 20(6): 809-837.

Erdal G, Erdal H, and Esengün K (2012). The effects of exchange rate volatility on trade: evidence from Turkish agricultural trade. Applied Economics Letters, 19(3): 297-303.

Faust J, Rogers JH, and Wright JH (2003). Exchange rate forecasting: the errors we've really made. Journal of International Economics, 60(1): 35-59.

Greenaway D, Kneller R, and Zhang X (2010). The effect of exchange rates on firm exports: The role of imported intermediate inputs. The World Economy, 33(8): 961-986.
Huchet-Bourdon M and Bahmani-Oskooee M (2013). Exchange rate uncertainty and trade flows between the United States and China: The agricultural versus the nonagricultural sector. Chinese Economy, 46(2): 29-53.

Klaassen $F$ (2004). Why is it so difficult to find an effect of exchange rate risk on trade?. Journal of International Money and Finance, 23(5): 817-839.

Lane PR and Shambaugh JC (2010). Financial exchange rates and international currency exposures. The American Economic Review, 100(1): 518-540.

Li H, Ma H, and Xu Y (2015). How do exchange rate movements affect Chinese exports?-A firm-level investigation. Journal of International Economics, 97(1): 148-161.

Olawale F and Garwe D (2010). Obstacles to the growth of new SMEs in South Africa: A principal component analysis approach. African Journal of Business Management, 4(5): 729738.

Rose AK and Spiegel MM (2010). Cross-country causes and consequences of the 2008 crisis: International linkages and American exposure. Pacific Economic Review, 15(3): 340-363.

Zmami M and Ben-Salha $O$ (2015). Exchange rate movements and manufacturing employment in Tunisia: Do different categories of firms react similarly?. Economic Change and Restructuring, 48(2): 137-167. 